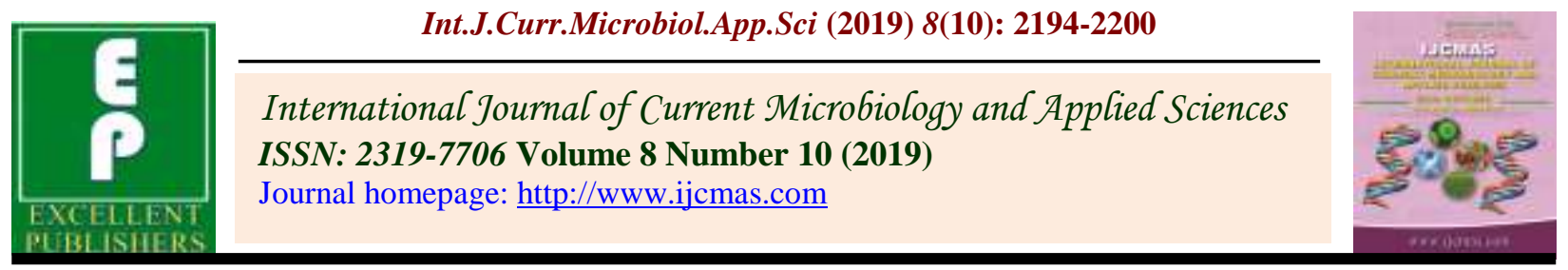

Original Research Article

https://doi.org/10.20546/ijcmas.2019.810.255

\title{
Effects of Soils on the Morphology of the "nyù", Yams of the Passoré in Burkina Faso
}

\author{
D. Tiama ${ }^{1}$, M. H. Ouedraogo ${ }^{1}$, M. Yolou ${ }^{2}$, N. Sawadogo ${ }^{1}$, P. Bationo/Kando ${ }^{1}$, \\ J. Zoundjihékpon ${ }^{2}$, M. Sawadogo ${ }^{1}$ and J. D. Zongo ${ }^{1}$
}

Equipe de Recherche en Génétique et Amélioration des Plantes

Laboratoire Biosciences

Unité de Formation et de Recherche en Sciences de la Vie et de la Terre

Université de Joseph KI_ZERBO, 03 BP7021 Ouagadougou 03; Burkina Faso

${ }^{1}$ Biosciences Laboratory of the University of Ouagadougou

${ }^{2}$ Ecological Genetics Laboratory of the University Abomey-Calavi

*Corresponding author

Keywords

Tuber, Crop,

Mineral, Organic fertilization, Ridges, Morphology,

Article Info

Accepted:

17 September 2019

Available Online:

10 October 2019

\section{A B S T R A C T}

This study aims at finding a concise understanding of the different modifications of the "nyù" noticed during the harvest. It specifically intends to give the effect of each type of soil on the morphology of the yam and on the choice of the producers. The results of this study shows that sandy soils produce tubers mostly appreciated with their filiform shape characterizing the "nyù". As to the studied variables (Length, Diameter and Weight of the tuber), any significant difference has not been observed.

\section{Introduction}

As the other West African countries, Burkina Faso is not known as a producer of yams. Generally, people cultivate yams in areas where the rainfall is higher than $800 \mathrm{~mm}$ of rain per year (FAO, 2008; Dumont et al., 2010). However, people cultivate the "nyù" which is one of the specific and endemic type of yams in the Passoré (Tiama et al., 2016a; Dumont et al., 1986). The "nyù" is cultivated in the Northern area of the country with a rainfall which is not suitable for the cultivation of yams from general view. The rainfall of this area is about $600 \mathrm{~mm}$ rain per year in average (Tiama, 2016). For this reason, diverse cultivation techniques have been adopted to produce the yam "nyù". These techniques are: crop rotation, association of crop, mineral and organic fertilization and retention of water by forming ridges around the farm (Tiama et al., 2016b). These techniques are used to improve the production and conservation of organoleptic qualities. 
The morphology and the texture of the yam "nyù" are not well seen when it comes to the unusual choice of soil for the cultivation. The yams known to conserve their filiform shape like the "nyù "' have sometimes a lot of hair on the tubers and some tubers ramified. After the harvest, the usual knowledge of the shapes of yams affects the choice of consumers. Producers interpret the shapes of yams in different ways: for some, the morphology of the yam is due to the producer and for the others, it is due to the passers-by. These different points of view have led us to carry out this study. The objective of the study is to provide a succinct answer to the different modifications of the yams at the harvest and find out the effect of each type of soil on the morphology of tubers.

\section{Materials and Methods}

The vegetal material is composed of some pieces of the morphotype "nyù" collected in 13 villages from 5 departments of the province of Passoré. Each sample of the collected morphotype from a peasant constitutes an accession.

\section{Enquiry}

An investigation has been carried out during a campaign from November 2017 to January 2018 in the eight villages of "nyù " producers in the commune of Arbollé. We have also used a questionnaire on the appearance of the tubers, the types of soils used for the cultivation of the yams "nyù".

\section{Experimental area}

Some experiments have been conducted in the season of 2017-2018 in order to let the yams develop better their agro morphological potentialities. These experiments were carried in the province of Passoré precisely in Mia, a village of the department of Arbollé as coordinates $12^{\circ} 50^{\prime} 56^{\prime \prime}$ in the North, $02^{\circ} 02^{\prime} 49.4^{\prime \prime}$ in the West and $345 \mathrm{~m}$ of altitude. Mia is located at $12^{\circ} 50^{\prime} 29^{\prime \prime}$ in the North, $02^{\circ} 03^{\prime} 48.1^{\prime \prime}$ in the West with $377 \mathrm{~m}$ of altitude. The annual rainfall is about $600 \mathrm{~mm}$. The type of soils in the experimental areas are mainly muddy soil or "sablaaga" (black) and sandy soil or "miougou" (red) in Mooré language. We started the experiments in January in the period of harmattan when the soil contains much wetness to conserve the seeds before the rainy season. At last, the seeds are put into jugs differently with the two types of soils for the observation of the effect on the tuber growth process.

\section{Experimental Instruments}

The experiments have been led by using a device in bock of Fisher repeating three times for each type of soil. Each repetition has been subdivided into forty one (41) ridges. Each ridge measures $2 \mathrm{~m}$. This allowed us to realize three repetitions per accession. As the total number we got 246 ridges for both types of soil: 123 ridges on sandy soil and 123 ridges on muddy soil. The repetitions have been separated from $2 \mathrm{~m}$ and the ridges from $0.5 \mathrm{~m}$. Each ridge contained five stems in the accession spaced of $50 \mathrm{~cm}$. Besides these types of soils, an experiment is carried out with jugs of $30 \mathrm{~cm}$ each. Every hole contains $120 \mathrm{~g}$ of organic fertilizer.

\section{Features observed}

Three quantitative features related to the production have been measured: the length of tubers (LTU), the diameter of the tuber (DTU) and the weight of tuber (PTU). As to qualitative features, the shape, the consistency, the colour of the peel and the pilosity of the tuber. Lastly, the preference of the tubers has been marked by a panel of actors of yam production (producers, sellers and consumers) as 60 peoples. 


\section{Data analysis}

The treatment and the analysis of the data collected have been carried out by using the softwares Excel, XLSTAT and Statistica version 6. The comparative analysis of the average between the different accessions has been done with XLSTAT software. The analysis of variance (ANOVA) is done by using Statistica software to determine the features that distinguish the tubers depending on the type of soil.

\section{Results and Discussion}

\section{Enquiry}

The results have shown that $51 \%$ of the producers of the yam cultivated on muddy soils. They inherited the farms from their parents. Besides, these areas are able to retain much water. However, all the actors of the "nyù" production prefer sandy soils. Their actual choice is due to the fact that the consumers are asking for the yams with smooth peel. After the harvest, the producers used to scrape the hair on the tubers produced on muddy soils in order to have smooth peels.

\section{Experimental results}

The obvious results were the colour of the tubers which was dependent on the colour of the type of soil. The tubers resulted from sandy soils have a bright colour and those produced on sandy soils are grey or black.

On the muddy soil, we noticed that the tubers have a high pilosity on all their length except their basal parts (Photo 1A).

The yams of the sandy soils have smooth peel and less pilosity. The tubers are longer than the tubers of the muddy soils (Photo 1B). The performances of the yams related to the different type of soils are consigned into the Table 1. The analyses of the accessions for each type of soil and between the two soils have not resulted in any significant difference.

The analysis of variance between the morphotype of the two soils has not resulted in any significant differences for the studied variables. They are the length, the diameter and the weight of tubers with successively a Fisher coefficient of 0,$27 ; 0,23$ and 1,96.

The correlation table between the values studied shows a positive correlation between tuber diameter and weight and negative between length and diameter.

\section{In the jugs}

The results obtained show that the tubers on sandy soils are $30 \mathrm{~cm}$ long in average with a digitate basal (Photo2A). As to the tubers in the jug containing muddy soil, we got ramified tubers on all their shape (Photo2B).

\section{Choice of the panel}

$80 \%$ of the panel members have chosen the tubers of sandy soil whereas, for $20 \%$ of the panel, the tubers are the same. This $20 \%$ of the panel are in general producers.

Two qualitative criteria seem to be known when cooking the tubers. The appearance and the taste should stay pleasant (Dumont et al., 2005). As to appearance requirement, the choice of the soil is always highly important for any culture. If the characteristics of the soil do not suit to the plant, many negative effects can occur at the harvest. Among these nondesirable effects, we can cite the lowering of the production and the preference of the actors for the chain of value (Dumont et al., 2005). In fact, as many people do not know the yam "nyu" like the other yams, its production needs more attention in term of the choice of the soil 
to better value it. Dumont et al., 2005, Yolou, 2016, in traditional cooking, people use the fresh tubers and this preference guides much the producers who are the first actors in the field of production. The actors choose the tubers for the smoothness of their peel and the filiform shape of tubers (Tiama, 2016).

The hairy appearance of the tubers is more observed on the tubers grown on muddy soils than on those of the sandy soils. These muddy soils have some elements characteristics of the natural environment of the yams "nyü". The wild yams (Dioscorea praehensilis and D. abyssinica) present this hairy appearance and thorny roots (Dumont et al., 2005). The apparition of the hair as the roots seems to be a kind of adaptation of the plant seeking for water. The muddy soil with a high capacity to retain water could have permitted the plant to develop its roots for absorption. These characteristics have been given by Dumont in 2005 on the wild yams of Benin forests. The length of the tubers is highly influenced by the fertility of soils (Dumont, 1969). Therefore, we can say that the muddy soils are the most favorable to show all the wild features of the "nyù" in domestication. The study has also shown that the most ramified tubers were cultivated on muddy soil. The different shapes observed on the muddy areas seem to be related to the obstacles affecting the tubers during their formation process. When there is a lack of rain, the muddy soil can harden fastly than sandy soil. The results obtained show that the yams of the sandy soil are the longest on the two sites. On the sandy soils, the tuber formation process seems easy because of the lack of obstacles (stones, soils hardening). The tubers into the jug have shown a ramification of tubers. The sandy soil is therefore more favorable for the lengthening of the tubers than the muddy soil. The jugs are not too long for the tubers formation and the ramification of the basal part of the tubers. The results have been observed on the different morphologies of the complex Dioscorea cayenensis-D. rotundata through the obstacles met when planting the cuttings by Dumont et al., en 2005. Unlike the other tubers, (taro or fabirama) which have the shapes specific to the varieties (Nanéma, 2010 and Traoré, 2014), the different shapes of the "nyü" are due to the obstacles occurred during the tuber formation process.

The positive correlation between length and weight shows that size affects yield, and the negative correlation between diameter and length shows that when tubers are large they do not gain in size. These results explain the high yields of Passoré yams, despite their size and reduced diameter.

The actors of "nyü" production choose the tubers cultivated on the sandy soils because they know yams at the edges of roads. Before arriving at the market, the producers remove the thorny roots from the yams. This is the reason why the tubers found on the market have a smooth appearance. People used to choose the tubers with smooth appearances because it seems that consumers find it easier to use for many purposes (farming, fries, stew, etc.).

This study has provided evidence on our question about the cultivation of the "nyù" in accordance with the type of soil and the appreciation of the tubers by the actors of the yam production. On muddy soils, the "nyŭ" tubers develop more absorbing hair than tubers on sandy soils. On sandy soils, the tubers keep their smooth, filiform and long appearances. However, it is important to know that the production on both types of soils is the same. The ramifications observed are due to some obstacles occurred during the tuber formation process. As to the actors of the "nyù" production, they have a special preference for the tubers grown on sandy soils (Table 2). 
Table.1 Average Performance of the accessions according to the type of soil

\begin{tabular}{|c|c|c|c|c|c|c|}
\hline $\begin{array}{c}\text { Type of } \\
\text { soils }\end{array}$ & Variables & Min & Average & Max & CV & F \\
\hline $\begin{array}{c}\text { Muddy } \\
\text { Soil }\end{array}$ & $\begin{array}{c}\text { LTU } \\
(\mathbf{c m})\end{array}$ & 6.7 & 20.75 & 55 & 0.41 & $0.68^{\mathrm{NF}}$ \\
\cline { 2 - 7 } & $\begin{array}{c}\text { DTU } \\
\text { (mm) }\end{array}$ & 42.2 & 74.23 & 105.5 & 0.25 & $1.00^{\mathrm{NF}}$ \\
\cline { 2 - 7 } & PTU (g) & 457 & 566.99 & 769 & 0.10 & $1.00^{\mathrm{NF}}$ \\
\hline \multirow{2}{*}{$\begin{array}{c}\text { Sandy } \\
\text { Soil }\end{array}$} & $\begin{array}{c}\text { LTU } \\
\text { (cm) }\end{array}$ & 31.5 & 44.12 & 60.2 & 0.15 & $1.15^{\mathrm{NF}}$ \\
\cline { 2 - 7 } & $\begin{array}{c}\text { DTU } \\
(\mathbf{m m})\end{array}$ & 37.56 & 54.92 & 68.86 & 0.13 & $1.77^{\mathrm{NF}}$ \\
\cline { 2 - 7 } & PTU (g) & 412 & 640.23 & 912 & 0.19 & $1.19^{\mathrm{NF}}$ \\
\hline
\end{tabular}

Key : Mini : minimum; Aver : average; Max : maximum LTU : length of tubers; DTU : diameter of tubers $(\mathrm{mm})$; WTU :weight of tuber. Cv : coefficient of variation; F : coefficient of Fisher

Table.2 Table of correlation

\begin{tabular}{|c|c|c|c|}
\hline VARIABLES & LTU & DTU & PTU \\
\hline LTU & $\mathbf{1}$ & & \\
\hline DTU & $\mathbf{- 0 , 3 1}$ & $\mathbf{1}$ & \\
\hline PTU & $\mathbf{0 , 5 2}$ & $\mathbf{0 , 0 3}$ & $\mathbf{1}$ \\
\hline
\end{tabular}

\section{Photo.1}

Photo.1A Tuber in the muddy soil

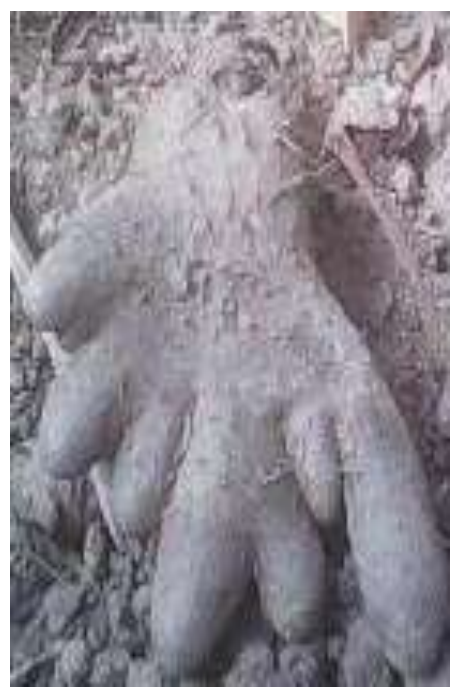

Photo.1B Tuber of the sundy soil

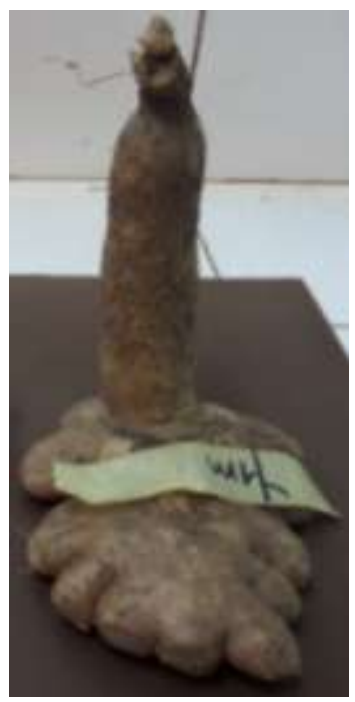




\section{Photo.2}

Photo.2A Tubers on muddy soil

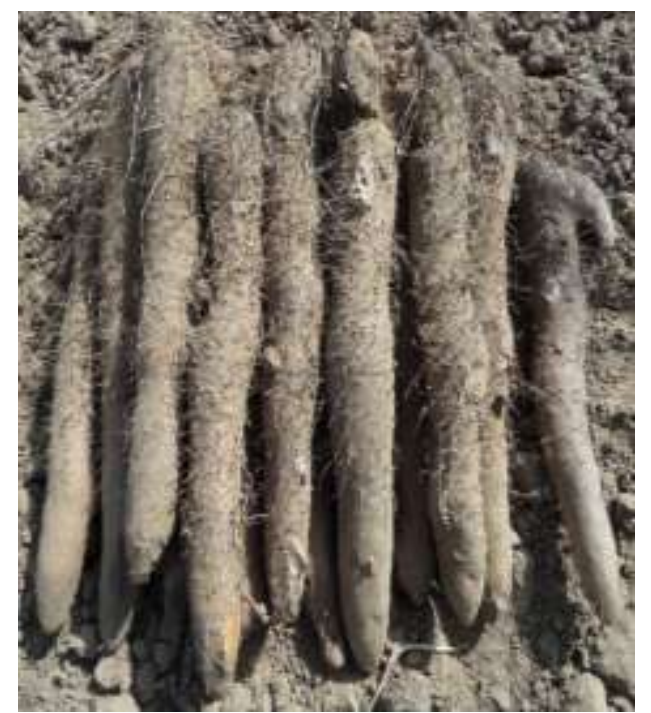

\section{References}

Dumont R., Vernier P., Zoundjihékpon J., 2010. Origine et diversité des ignames Dioscorea rotundata Poir. Cahiers Agricultures. 19(4) : 255-261, 2010.

Bénin des questions de droits de propriété intellectuelle. Thèse de Doctorat de l'Université d'Abomey - Calavi, Bénin ; 155p.

Dioscorea cayenensis - D. rotundata et $D$. dumetorum) et perception des paysans du Centre -

Dumont R. et Hamon P., 1986. Une forme originale parmi les Dioscoréacées cultivées en Afrique d de 1'Ouest : l'Igname de Pilimpikou, rapport 1986.

Dumont R., 1969. Ignames du Bénin. IRAT DAHOMEY 1969.

Dumont R., Dansi A., Vernier P., Zoundjihékpon J., 2005. Biodiversité et domestication des ignames en Afrique de $1^{\prime}$ Ouest. Pratiques traditionnelles conduisant à Dioscorea rotundata. Collection repère. Montpelier: CIRAD, éd., 2005.

Dumont R., Vernier P., Zoundjihékpon J.,
Photo.2B Tubers on sandy soil

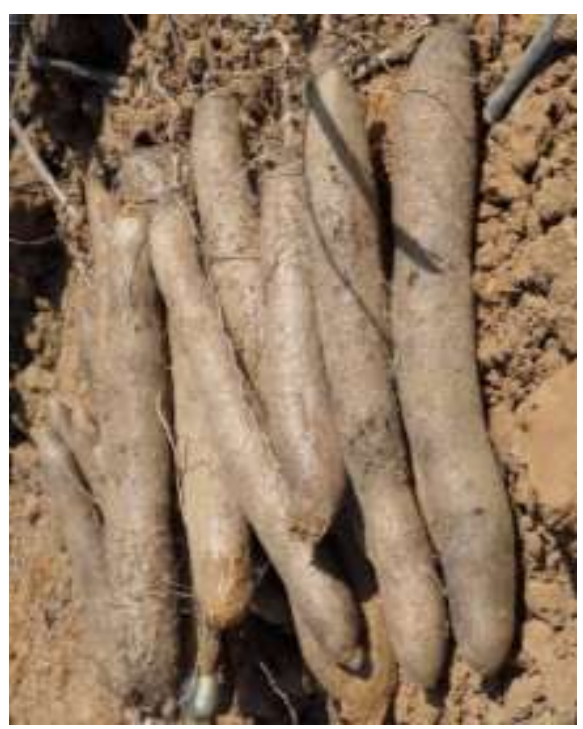

2010. Origine et diversité des ignames Dioscorea rotundata Poir. Cahiers Agricultures. 19(4) : 255-261.

Nanéma R. K., 2010. Etude de variabilité agromorphologique de Solenestomon rotundifolius (POIR J.K. MORTON) et des relations phylogénétiques entre ses différents morphotypes cultivés au Burkina Faso. Thèse. Univ. Ouagadougou, UFR/SVT. 122 p.

Tiama D., 2016. Diversité génétique des ignames Dioscorea $s p$ du Burkina Faso : yùyà du Passoré. Thèse de Doctorat unique, Univ Ouaga 1 Pr Joseph KIZERBO. p 171.

Tiama D., Zoundjihékpon J., Bationo/Kando P., Sawadogo N., Nébié B., Nanéma K. r., Traoré R. E., Tao I., Sawadogo M., Zongo J D., 2016a. Les ignames, « yùyà », de la province du Passoré au Burkina Faso. International Journal of Innovation and Applied Studies ISSN 2028-9324 Vol. 14 No. 4 Feb. 2016, pp. 1075-1085.

Tiama D., Zoundjihékpon J., Sawadogo N., Bationo/Kando P., Sawadogo M., Zongo J D., 2016b. Agro- 
morphological characterization of yams (Dioscorea $s p$ ) of Passoré in Burkina Faso. ISSN: 2090-4274 Journal of Applied Environmental and Biological Sciences.

Traoré E.R., 2014. Etude de la diversité du Taro (Colocasia esculenta (L.) Schott) : cas d'une collection du Burkina Faso et d'une collection internationale. Thèse, Univ. Ouagadougou, Burkina Faso, 161p. ignames africaines cultivées (Complexe

Zoundjihékpon J., 1993. Biologie de la reproduction et génétique des ignames cultivées de l'Afrique de l'Ouest, Dioscorea cayenensis-rotundata. Thèse n 194. Vol. Université Nationale de Côte d'Ivoire, Faculté des Sciences et Techniques. Abidjan, Côte d'Ivoire. $306 \mathrm{p}$.

Yolou M., 2016. Diversité génétique des

\section{How to cite this article:}

Tiama, D., M. H. Ouedraogo, M. Yolou, N. Sawadogo, P. Bationo/Kando, J. Zoundjihékpon, M. Sawadogo and Zongo, J. D. 2019. Effects of Soils on the Morphology of the "nyù", Yams of the Passoré in Burkina Faso. Int.J.Curr.Microbiol.App.Sci. 8(10): 2194-2200. doi: https://doi.org/10.20546/ijcmas.2019.810.255 